\title{
Fight Silently: Everyday Resistance in Surviving State Owned Enterprises in Contemporary China
}

\author{
Ju Li, Binghamton University, Sociology Department
}

\begin{abstract}
ABSRACT
Many scholars have noted the rise of labor militancy in contemporary China. This rise is often linked to the growing discontent of an expanding working class facing harsh market conditions. We might expect workers in state-owned enterprises, which have suffered statecut backs and harsh privatization, to be among the most militant. This study reveals, however, that workers at one of such state-owned enterprises are far from militant. I argue that the urgency of survival and the denial of alternative work opportunities have effectively prevented any form of collective resistance on the part of these workers. Instead, their resistance only manifests in forms of so-called everyday resistance. Furthermore, these forms of resistance work as a double-edged weapon with harmful consequences for both the regime and its workers.
\end{abstract}

\section{KEYWORDS}

everyday resistance, labor movement, neoliberal policy, state-owned enterprise workers

\section{Introduction}

Labor unrest, whether in the form of collective confrontations or law suits, has increased dramatically in contemporary China. Recent statistics from the Supreme People's Court showed that the number of participants in industrial disputes in China has grown from around 10,000 in 1993 to 317,000 in 2009, with the total number of participants increasing from 0.7 million to over 5.4 million (China News 11 March 2010). This means that in 2009, approximately one fourth of China's 21.7 million industrial workers (China Statistic Yearbook 2009) were involved in some form of labor dispute. Similarly, according to one scholar's estimation (Yu 2010), in that same year, there were around 90,000 mass incidents throughout China, one third of which were labor-related. This puts the number of strikes and collective worker protests in 2009 at around 30,000.

Such widespread labor militancy has caught the attention of labor studies scholars both within and outside of China, and numerous accounts of these labor movements have been recorded and analyzed accordingly (Cai 2002; Pei 2003; Lee 2007; Ngai, Chan and 
Chan 2009). Beverly J. Silver and Lu Zhang (2009), in a recently published article, claim that, along with the mass movement of capital into China and the deepening commodification of labor, a consolidated Chinese working class has finally been created that responds to economic transformations through collective organization and even revolutionary actions. Their argument speaks to the turbulent labor formation process and labor movement development in contemporary China, where workers are having to adjust to, negotiate with, and fight against the oppressive labor regimes that have accompanied China's great transformation from an autarkic socialist country to a major player in the framework of neoliberal global capitalism.

Amidst all this turbulence and excitement, however, there is another form of resistance that has been constantly and, to a certain degree, understandably dismissed - the so-called 'everyday resistance' famously identified and examined by James Scott (1987). This kind of long-lasting resistance, with its more spontaneous, individualized, subdued, and relatively safer manifestations, is always adopted by subordinated social groups in human history (Hobsbawm 1965; Bloch 1970; Gaventa 1980; Oi 1991; Friedman, Pickowicz, Selden and Johnson 1991). This study aims to re-explore and re-evaluate this easily ignored, but prevalent form of resistance as it is enacted by Chinese workers, either as a complement to open collective resistance or as the main or sole form of resistance to the massive transformations of China's entry into globalized capitalism. It investigates how workers have responded to the sharp deterioration in their living and working environment caused by neoliberal market reform, from the middle of the 1990s to the present, in one particular state-owned enterprise (SOE), Nanfang Steel (NS). I argue that when confronting the same general capital movement and labor commodification and accordingly degradation, in reality, workers have to face concrete conditions and hence generate various forms of responses and resistances. As James Scott (1987: xv) reminds us at the very beginning of his brilliant study of Malay peasants' resistance against agricultural capitalization, 'most subordinate classes throughout most of history have rarely been afforded the luxury of open, organized, political activity' since 'such activity was dangerous, if not suicidal.' In the case I examine, the urgency of survival and the denial of alternative work opportunities have effectively prevented any form of collective resistance on the part of NS workers. Though there is great resentment and even hatred toward the management in their minds, the workers at NS are far from militant. Rather, they are generally compliant - at least ostensibly. Their resistance manifests in much more subdued, spontaneous, and individualized ways: back-stage rumors and curses, apathy, foot-dragging, feigned ignorance, pilferage, and so on - the typical 'weapons of the weak' (Scott 1987).

Such forms of resistance can easily be denigrated as trivial and unimportant and thus ignored, and the predominant focus on collective labor movements within Chinese labor studies reveals precisely this tendency. Even among the very few studies that acknowledge and investigate 'everyday resistance' among Chinese workers, scholars tend to imply the phenomenon is negligible and ineffective, rather than significant. For example, Ching Kwan Lee (1998), in her article illustrating SOE workers' responses toward market reform in the late 1990s, chooses the term 'collective inaction' instead of 'everyday resistance' to describe 
workers' individualized resistance toward the regime. The former term implies that such resistance is negligible as long as workers remain collectively inactive. The term was also adopted later by Aiyu Liu (2005) and applied to her study of workers' responses toward reform in five SOEs from four different cities (Shanghai, Shengyang, Nanning, and Taiyuan) in the middle of the 2000s. Similarly, Liu noted the general existence of collective inaction among workers in these enterprises, but she went even further to claim that it was precisely this inaction on the part of workers that has guaranteed and will continue to guarantee the smooth execution of further SOE reform in China. Both accounts, while acknowledging the existence of everyday forms of resistance among workers, regard such resistance as insignificant, inconsequential, and, hence, ignorable. This view, which is unfortunately shared by many others, risks missing something essential. It is akin to confining one's investigation only to the violent eruptions of a volcano, while totally disregarding the subdued magma flow beneath the surface - when it is, in fact, this action beneath the surface that determines whether, when, why, where, and how the volcano will erupt. Scott, in his work, has hence rebutted such denigration of everyday resistance by pointing out that while such actions may not make headlines, they can nibble away at the legitimacy of the system in the long run, and 'make an utter shambles of the policies dreamed up by their would-be superiors in the capital' (Scott 1987: xvii). To prove this argument, he elaborates in great detail and depth how the everyday resistance adopted by Malaysian peasants against their oppressors has at least delayed the complete transition to capitalist relations of production in the countryside.

My research of NS has similar, but distinct findings. At NS, workers' everyday resistance has two meaningful consequences. On the one hand, it has delegitimized the controlling power of the management, provoked other forms of collective inaction among the management (e.g., hesitant and apathetic labor control on the shop floor), damaged the production process, and hence ridiculed the whole reforming agenda, causing its failure. On the other hand - and this is the aspect not explored by Scott - the NS workers' everyday resistance has actually gone against their previously shared work ethic, distanced them from their work, shattered their sense of honor and pride, and strengthened their feelings of inadequacy and powerlessness. In short, the everyday resistance adopted by NS workers has worked as a double-edged weapon with harmful consequences for both the regime and its workers.

In this article, I begin by providing a brief introduction of my case enterprise, Nanfang Steel, especially its particular neoliberal reforming process, and the social consequences that have followed. I then discuss NS workers' responses to their deteriorating working and living environments, specifically, their particular forms of daily resistance. I go beyond simply noting these forms of resistance, however, and examine their consequences also, showing how they have paradoxically shaped the fate of both the regime and its workers. In conclusion, I then highlight the constraining power of the system against workers' options for resistance. 


\section{Surviving Marketization: Reform and Its Consequences in NS Steel}

Located in the mountainous area within the province of Sichuang, Nanfang Steel, an essential steel production site in southeast China, is an immense state-owned enterprise that was developed as one of thousands of 'third-front enterprises' during the Third Front Construction (TFC) era in the 1960s. The objective of Third Front Construction was to create an entire industrial system within the Chinese hinterland - the naturally remote and strategically secure region - as a direct response of socialist China to military threats, primarily from two imperialist powers, the U.S. and the U.S.S.R., during the Cold War (Chen 1997; Ma 1998). The Front was meant to serve as a large-scale industrial network, linking the entire interior area through major transport and industrial facilities. During its heyday of the late 1980s and early 1990s, NS was one of the biggest taxpayers in Sichuan province and employed around 30,000 workers. Even today, after more than half of its workers have been laid off or have simply retired, it is still the largest and most significant employer in the area, with around ten thousand workers.

In the mid-1990s, a variety of market-oriented means (bankruptcy, merger, privatization, downsizing for efficiency, burden alleviation, large-scale lay-offs, and so on) were encouraged by the central state to reform the so-called 'inefficient' SOEs, including NS. Instead of revitalizing them, however, these programs have brought large-scale bankruptcy and privatization of small and middle-sized SOEs nationwide, and incurred great anger among newly-unemployed/laid-off workers in many parts of the country (Blecher 2002; Cai 2006; Chen 2006; Lee 2000, 2002, 2007; Gallagher 2005). Responding to the increasing unrest and grievances, the central government has slowed down bankruptcies and huge layoffs since 2002 in the remaining large SOEs, largely for the sake of stability and legitimacy. Among these remaining large SOEs, some 'have managed to prosper throughout China's economic boom' (Chan and Unger 2009: 2). These include 150 or so key enterprises owned and controlled by the central state (Dyer and McGregor 2008) and a few others that have 'adjust[ed] successfully to the introduction of a market economy' (Chan and Unger 2009:1). Still others have actually failed the reform but have been saved from collapse for the political consideration of stability. For them, final bankruptcy has been staved off, but instead, most of them have simply been dragged into a slow and painful dying process (Huang 2006).

NS is one of these ailing, yet surviving SOEs. In NS, turbulent marketization combined with the preservation of the factory has produced dramatic social changes with unsettled consequences. First, there is the formation of a despotic factory regime on the shop-floor. In NS, efforts to set-up a modernized enterprise by building up an effective 'incentive mechanism' and setting up 'scientific management' have not saved the enterprise from chronic losses. Rather, the result has been the creation of a coercive, yet apathetic regime in which piece-rates and strict economic penalties serve as the two primary methods of labor control. Together, these measures have produced a strong sense of labor alienation among workers in NS. ${ }^{1}$

Secondly, wage reform and welfare reform, both adopted since the mid-1990s, have further impoverished NS workers and led to the disintegration of the working-class community. Even though the average wage for NS workers has increased from around 1000 
Yuan in 1980 to 10,000 Yuan in 2009, that number is still far below the average wage in Sichuan Province - 23,191 Yuan (People's Daily: Sichuan 15 May 2010), and the increase is completely overmatched by the skyrocketing increase in living expenses. Furthermore, the wage gap between managers and workers within NS has increased tremendously. The average wage of managers is ten to thirty times that of workers, and if we take into account the socalled 'under-the-table' money that is available to members of management, the gap is likely even wider.

At the same time, along with widening wage disparities, the so-called welfare reform - which refers collectively to house reform, education reform, and medical reform - has smashed the safety net previously provided by the SOE and contributed greatly to the disintegration of the NS community, a previously fully functioning, consolidated, and prosperous mini-kingdom supported by the enterprise. Now, instead, a segregated workingclass slum has emerged within the old NS community. ${ }^{2}$ Rather than relying on enterprisesubsidized dwellings, education, and health care, people now have to purchase these goods and services from the market, where costs vary dramatically. With their meager income, workers soon find out that the only options available to them are the lowest-grade ones. These days, they can only afford to obtain medical services from the previously enterprisesponsored, but now stripped-down hospital with poor medical equipment and services due to investment shortage; they buy or rent the destitute, but relatively cheaper apartments built up by the enterprise mostly in the 1980s, in the old working class community; and they are forced to send their kids to the local, low-quality public schools within the neighborhood in which they are now living. Yaping, one female worker in her 30s, took the example of education and complained to me:

'Everything now is going back to how it was before the liberation [1949]. Before, kids from the poor family couldn't afford to go to school. Now, poor kids can't afford to go to school again. All the sacrifices and efforts our martyrs made for this country are betrayed'.

When Yaping complained about the cost of education, she did not mean that working-class children cannot go to school at all; rather, she was lamenting that they can only afford to go to the low-quality, local public schools, thus risking their future because their parents can't afford the dwellings in the nearby city, where public schools, health care, and other basic infrastructures are far better - and where, not incidentally, all the NS managers choose to live.

Yaping's point applies to other aspects of life. It is not that ordinary NS workers cannot afford dwellings, it is that they can only afford shoddy ones; it is not that they cannot afford apparel or food, it is that they can only afford the cheapest ones; and so on. The complaint is in response to a paradoxical situation, in which living standards have generally improved, but they have also become marked by stunning inequalities - something that is still new to most workers who either experienced or remember a past era when working-class kids and managers' kids went to the same schools, and workers and managers lived in the 
same buildings or neighborhoods, went to the same hospital and stores, and celebrated holidays in the same hall. In other words, it is not so much the absolute poverty - the starvation, malnutrition, or homelessness per se - that distresses NS workers, but the strong sense of being marginalized and excluded from other, more promising, decent, and prosperous options that are saved for richer people, including NS managers.

In sum, all of these changes - the shift to a despotic factory regime, the increase in workers' relative poverty, and the disintegration of any shared sense of community - have marginalized NS workers to a great extent. The turbulent neoliberal reform and the following preservation of NS from bankruptcy have exempted workers from abject poverty, but forced them into an undignified, degraded, and subordinate way of living. This degradation is keenly and painfully sensed by many common workers, as pointed out by Weijie, a female worker in her late 40s:

'Yes, we do have more things to buy in the market and the consumer goods are much richer than before. So what? We could eat better? Wear better? Is that all? I think now we are living like animals'!

Stating that workers are 'living like animals' is a desperate cry from common workers for the dignity and respect that they have lost under the current regime, a loss so fundamental that it cannot be compensated by the abundance of material commodities offered by the emerging consumerist society. As I observed in the field, dismay and desperation were actually everywhere. But, have all these conditions thus fostered a militant working class that is responding to these adverse social changes with collective and open confrontations? I explore this question in the next section.

\section{Fight Silently: Everyday Resistance in NS}

In her global narrative of labor unrest in the past 130 years, Beverly Silver (2003) identifies two types of labor unrest: Marx-type and Polanyi-type. Marx-type unrest mainly refers to workers' struggles against capitalist exploitation in production. Polanyi-type unrest, by contrast, refers to the 'backlash' resistance from those workers who had benefited but are recently 'unmade' from established social compacts. Both types are absent from the currently-employed workers in NS. ${ }^{3}$ In fact, despite being faced with continuously degenerating social status and living and working environments since the 1990s, NS workers have never organized any forms of collective resistance, not even once. Instead, they are, at least ostensibly, acquiescent and resigned. However, it would be cursory to conclude that these workers are just passive victims who tamely submit to the oppressive external power/order and fatefully accept an uncontrollable destiny. Indeed, my ethnographic research reveals that many workers have actually harbored great resentment and even hatred, mostly against the management, and tactically expressed these feelings in more surreptitious, spontaneous, and individualized ways. That is to say, NS workers have employed their 'weapons of the weak' in ways quite similar to those of the Malaysian peasants in Scott's 
study - ways that include ostensible conformity, backstage rumors and curses, and shop-floor non-confronting resistance.

\section{OSTENSIBLE CONFORMITY}

On the shop floor, according to my observation, workers rarely confront their direct managers, the section chiefs. Usually, workers are obedient, with a small number of them being apparently deferential or even adulatory, and most others passively compliant. One day when Aqiu, one electrician in his late 30s took me with him to his shift, we met his section chief at the entrance of the workshop. The section chief didn't say a word about my presence there, but scolded Aqiu very sternly for not wearing a safety hat. Aqiu just stood there and listened with his head hanging down. Later, when I asked him whether he felt humiliated at that moment, he replied:

'Not really. It was good that he didn't deduct my money.... You have to think in this way: as long as you are eating from their bowl, you have to obey their rule. Only if I don't want this job, I can yell back at you when I feel unhappy...'.

In this case, Aqiu suppressed his possible anger because of anxiety about possibly losing his job, but he also had to convince himself that this was, indeed, part of the game one has to play in order to get over the feeling of inadequacy and humiliation. He had to admit that he was inferior by nature to his manager since it was he, Aqiu, who 'had to eat from their bowl' as if he was a beggar, instead of a worker who was honorably exchanging his labor power for a deserved wage.

Very similar submissive responses can be found under different situations, for example, when workers are subjected to work overload, asked to work longer, or even to work under perilous conditions; most workers rarely or only slightly resist. Dagang, another electrician in his early 40 s, related a typical incident that happened at his work:

'In the past, two electricians were always required to do the job together, with one working and another one overseeing to assure the safety. Now with the downsizing of workers, we have to work by ourselves, which increases the risk of accidents to a great extent. One time, I was on my duty by myself when the heavy rain damaged the circuits and the master switch was tripped. The production had to stop. So the manager asked me to turn on the switch. I told the manager that since the switch tripped because of the short circuit, it was very dangerous to forcefully turn it on. He said that he couldn't stop the production and I had to go. Then I asked for an assistant to help me. The switch was near the top roof. Even if I climbed into the overhead traveling crane, I couldn't reach it. From there, I still had to climb up a ladder to reach the switch. I needed another worker to at least hold up the ladder for me. Later he found out another electrician from other sector for me. I told that electrician, "We should not take the risk to do that, but the manager is forcing us. 
What should we do"? He replied, "What should we do? Maybe bet our lives for good luck". (Laugh) At last, we decided to turn off all the switches in the workshop first, then turn on the master switch, then turn on the other small switches one by one. Luckily, we adopted this strategy, since when we turned on the last small switch, it exploded. It was a small one, so we were fine; if we had turned on the master switch first without turning off all other switches as the manager demanded, it would definitely have exploded and most probably we would have died. There are so many accidents these years, here or there. So I have to be very careful'.

Since the incomes of workshop managers are now directly related to output, production is always prioritized over safety. In the instance described by Dagang, as in many other cases, production output outweighed workers' safety without any hesitation on the manager's part. The industrial accident rates have rocketed in NS recently, since the factory is now reluctant to spend money on the safety measures it maintained before, and managers, under the pressure of production quota, are more likely to neglect such measures. When confronting the coercive dictates from managers, even in matters with life-or-death consequences, most workers simply 'bet their lives for good luck' and obey. 'You have to do your job, nothing there to be argued' is just the cruel reality forced upon NS workers and they clearly realize it.

The reasons behind such compliance and resignation are quite simple: workers' fear of losing their jobs and their clear recognition of their disposability. Zhangyong, a steel worker in his early 30 s, explained it in his own words:

'Who need our workers? Now there are so many peasant workers rushing into the cities. There is nobody to do the job? Just go to the labor market and yell, "I have some jobs here, want to come?" People will surely rush to you like a swarm of bees. So our workers are just shit'.

The fear of being fired comes from workers' memory of the large-scale lay-off in the late 1990 s, when around one half of them were laid off in different ways. Even though such huge lay-offs have ceased since 2002 and the process of firing now has to comply with the labor contract signed between the enterprise and workers and thus can't be too arbitrary, the fear of losing their jobs still haunts the minds of currently-employed workers. At the end of 2008, when the so-called global financial crisis brought another economic downturn nationwide, as well as in NS where losses that year reached 39.3 million Yuan (NS Annual Report 2008), rumors quickly spread among workers in NS that all workers would be laid-off, and then only a very small proportion of them would be chosen and re-employed. Almost everybody expressed the same pessimistic concern that 'we are in the same situation as we were in the 1997 (when the large-scale laid-off happened).' The purported huge lay-off has yet to happen, but the threat is always looming.

On the other hand, the hope of finding a suitable job outside NS is dim. When competing with the large labor reserve army that includes migrant workers from the destitute countryside, laid-off workers from bankrupted SOEs, and freshly-graduated students from 
colleges, these currently-employed workers, many of whom possess only manual or limited skills and are middle-aged, are at a severe disadvantage. In the 1990s, when the market reform of NS was in its most turbulent phase - many workshops in NS were closed; many workers were either laid-off or sent on long, unpaid vacation due to the closure of workshops; and the enterprise kept on delaying its paydays - many workers I interviewed took advantage of this period to try their luck in the outside world. Some of them went to work in the township and village enterprises (TVEs), others in the private enterprises, but all as manual workers. Most of them ended their 'outside' journey by returning to NS when the radical marketization phase ended and some production returned to normal in the early 2000s. Aqiu, the electrician in his 30s, explained his return to NS after working in a private factory for a few months in the following manner:

'The living expenses were much higher outside. After all these expenses including rents and transportation fees, I had little left to send back to my family. It was not worth it to leave my wife and my kid behind with so little contributions I could make to them'.

Qin Jie, one female worker in her early 40s, worked for a private employer as a bookkeeper before she came back to NS:

'I believed that my boss must be a criminal before. He was so rude and uncivilized. But he had a very strong background and the official network. You didn't know how bad he treated his workers, as if they were animals! He didn't treat them like person. So one day after a big fight with him, I quitted'.

Another worker, Yong, returned to NS after he was employed as a steelmaker in a private factory for three months because his retired parents in NS insisted he do so: 'They threatened to cut off the relationship with me.' Later, his mother explained to me:

'He is just a steelmaker, without higher education or advanced skills. Now he has strength, but soon the strength will go. Besides, who knows how long these private little factories could survive? Numerous have already been bankrupted. No matter how bad NS is now, at least relatively it is more secure'.

His mother's concern is not unjustified. Yong himself admitted to me that one of his friends who worked in a private steel factory was fired after breaking one of his arms there. The unregulated outside labor market has not brought the 'better life' promised by the 'free market'; instead, it has further strengthened the subjugation of workers, locked them into the most disadvantaged positions within the labor market, and thus excluded them from it to a certain extent.

In this sense, the preservation of NS has indeed saved NS workers from becoming members of the millions upon millions of dislocated labors swarming in the export-oriented 
globalized sweatshops in the South or simply becoming unemployed. But on the other hand, it has also created a permanent possible threat to workers, constantly reminding them of the fragility of their jobs and how easily and sometimes arbitrarily they could be taken away. Based on this understanding, we can see that workers' compliance is far from their 'backwardness' or 'cowardice,' but actually quite self-protective and pragmatic: it is against the threat of job deprivation. As Scott (1987: 279) puts it, 'his effort and his achievement, in one sense, have been to swallow his anger lest it endanger his livelihood.' But it can be a very hard thing to swallow for many workers and, indeed, even when it is swallowed, it is always accompanied with humiliation, resentment, and even hatred.

\section{RESENTMENT, RUMORS AND CURSES}

Almost every worker I interviewed harbors strong resentment toward the factory's management, referring to this specific group of people as 'Dang Guan De' (people who hold power). They use expressions like 'those people are not human' or 'they are merely ghosts' to express their indignation and resentments. During the interview with Dayong, a steel worker in his early 30s, he spent one third of his time cursing the managers in NS. When he talked about a case of theft that happened in his workshop two years ago, he angrily attributed the theft to the managers in the workshop:

'You know, what had been stolen were tons of Ni Plates. That was a lot. How could the common workers steal them out? ... We all believe that those 'dang guan de' did some tricks on the accounting books. When the Ni plates were claimed being ordered from outside and then stolen, our workshop was on temporary shutdown. So who knows? ... When the cops talked to us, we all told them to investigate the case thoroughly, find out the thief (thieves), and shoot him (them) to death'.

He emphasized the point that these managers should be shot to death at least three times during the interview. Dayong is not a particularly tough or militant worker in any sense. He is a hard-worker in other people's eyes and used to be a team leader. But Dayong is not alone; in fact, it seems that resentment is actually hidden in every worker's heart. During my time in NS, whenever workers gathered together, management corruption was always one of the most popular topics: which one embezzled a huge amount of money (the amount of which was always ridiculously high, and most likely, exaggerated); which one just bought another apartment in the city or a luxurious car; which one sent his/her kid to an expensive private boarding school; and so on. And the workers usually ended all these stories with curses, such as 'these fuck bloodsuckers will die as dogs' or 'they should be shot to death.'

Very similar to the observations made by Eszter Bartha (2005) of the Hungarian state workers who blamed everything except the system for their negative experiences after transformation, in NS, workers' indignation was directed only to managers as a group, who were condemned as 'betrayers of the enterprise' and 'greedy bloodsuckers of workers' labor.' Many workers declared that NS's problems had nothing to do with the command economy 
or market economy, but were due entirely to the corruption of managers. Frances Fox Piven and Richard A. Cloward (1977: 20) attribute such interpretations to workers' inability to abstract their immediate concrete experiences to the macro-level transformation, since 'workers experience the factory, the speeding rhythm of the assembly line, the foremen, the spies, the guards, the owner, and the pay check. They do not experience monopoly capitalism.' Scott (1987: 43), by quoting Piven and Cloward, reaches a similar conclusion about the Malay peasants: since they did not experience 'the cash nexus or the capitalist pyramid of finance,' 'the poorer strata of Sedaka see the causes of their present distress as primarily personal (that is, a result of human agency), local and largely confined to the Malay community' (1987:181). However, this explanation does not totally apply here.

In NS, workers are actually experiencing both the outside macro change and the inner micro change at the same time, but in quite contradictory ways. They learn from the mass media and witness for themselves the rapidly prospering country with dazzling skyscrapers, grand projects, luxurious commodities, and newly-affluent people with seemingly unlimited money. But simultaneously, they watch themselves sinking into desperation and poverty, and their community sliding into incessant decline. In other words, they are experiencing the transformation in a process of 'abjection,' as defined by James Ferguson (1999: 236) as 'a process of being thrown aside, expelled, or discarded' from the track of development, progress, and modernity that China now claims. Such highly contrasting and contradictory experiences bewilder and frustrate many workers as Xiaozhang, one worker in his middle 30 s complained to me:

'No matter how this enterprise or this country changes, we workers work as before, but now with so little pay... People like us couldn't understand the stuff about the reform, but we could feel the pain in the grassroots enterprise'.

Even though they might sense the changing attitude of the state toward the working class ${ }^{4}$, workers cannot confidently blame the state or the system since it is seemingly leading the country out of the status of a poor and underdeveloped third-world country previously suppressed by the West and granting 'nationalist pride' to the Chinese people as members of an emerging superpower in the world. As a result, they focus all their ire on management (and sometimes themselves, as I will analyze later) for their marginalization and abjection, and direct their resentment and hatred there.

\section{EVERYDAY RESISTANCE ON THE SHOP FLOOR}

Besides the backstage curses and rumors against the management, workers also strategically channeled their resentment and grievances in various negative ways on the shop floor. While absenteeism, tardiness, and resistance to discipline have been partially suppressed by strict financial penalties in recent years, foot-dragging and indifference have become the most prevalent forms of daily resistance. Almost all the workers I interviewed described their work as 'muddling around in the workplace.' Many workers explained to me 
'I go to work every day. Anyway that is how you get paid. But I only do the part that I have to do; never do more' or 'we work lazily and loosely, trying to avoid responsibilities.'

When facing strict labor control at the production site, many workers adopted strategies of apathy and indifference. These strategies are characterized by workers' seeming resignation, rooted in a strong sense of powerlessness, but accompanied by feelings of cynicism and suppressed resentment. Abin, a mechanic in his 30 s, described it in this way:

'Before, when we were maintaining the equipments, we tried our best. If there were damages here, we would think that maybe there were damages there. So we made a total check and fixed everything; now if there are damages on this spot, the manager would say, "You have to fix this in five minutes, otherwise...". When we bring apart the equipment, we might realize that the real reason for the damage on this spot is actually caused by problems from someplace else. But the manager doesn't know this. He might just say, "Quick, replace this with a new one". Our workers then say nothing too. We just do what he tells us and replace the bad hardware. After several hours, oh-oh, the equipment is out of order again. The manager doesn't know what happened and becomes disturbed a lot. And our workers don't say a word'.

In this way, workers express their indifference and even disdain toward their managers. By standing aloof, watching the machine break down again and again and cynically enjoying their managers' inability to do anything, workers exact revenge in their particular ways. When even grievances and sense of resentment have to be oppressed, workers turn to their own labor and skill as the weapon of last resort by withholding or hiding them from their oppressors, the managers. Such low-profile technique avoids workers' outright defiance of their managers, but endows them a secret power to counterbalance, even if only to a small degree, the arbitrary and dominant power of the management.

Meanwhile, the amount of pilferage has increased dramatically in recent years, according to the superintendent in the security department of NS. The workers I interviewed also admitted to me that stealing valuable alloys or any other materials from the enterprise was a very common behavior among workers. One worker estimated that about one third of workers were involved in various kinds of theft. Even though theft would be strictly penalized if discovered - the guilty worker would either be fired or jailed - many workers still choose to take the risk. To some extent, such deeds have been justified and tolerated by many workers as a desperate strategy for survival, as one worker angrily put it, 'how much did we put in and how much did we get? How could we workers survive with several hundred Yuan per month in this society'? Besides poverty as a rationale, theft is definitely one form of resistance performed by workers against corrupt managers and bureaucrats, as illustrated by a common saying among workers: 'people in the top steal big; people in the middle steal middle; workers in the bottom steal small'. The hidden inference here is that when compared with the large amount of money that corrupt managers embezzle from the factory, workers' petty thefts amount to nothing. Many workers acknowledged that they would look the other way if they happened to catch somebody in the act of theft. 
All these forms of everyday resistance adopted by NS workers under the camouflage of ostensible conformity - backstage rumors and curses, foot-dragging, suppressed apathy and pilferage - are actually the only means left for these workers to express their strong sense of deprivation and inadequacy, without seriously jeopardizing their and their family's survival. Such actions are spontaneous, yet rational. And in ways both positive and negative, these particular kinds of resistance have also generated some insidious and far-reaching consequences.

\section{Two-edged Weapon: Paradoxical Consequences of Everyday Resistance in NS}

The forms of everyday resistance in NS outlined above have generated two different,

yet co-existing sets of consequences. The first is the slowly corrosive or 'nibbling' effects against the regime as James Scott (1987) has described. The second, dismissed by Scott, is the detrimental effect of such resistance strategies for NS workers themselves. Combined, these double-edged effects, I will argue, have dragged both the factory and its workers into dilemmas.

\section{COLLECTIVE INACTION WITHIN THE MANAGEMENT AND THE IMPASSE OF PRODUCTION}

Needless to say, workers' superficial compliance masking actual non-cooperation has greatly damaged the production process on the shop floor. Quite a few managers expressed to me their frustration and dismay toward workers' non-cooperation and even hostility on the shop floor, and claimed it was very difficult to manage a smooth production process there. Importantly, instead of provoking more coercive labor control, such forms of silent resistance from workers have effectively delegitimized and undermined the controlling power of the management and induced a particular form of collective inaction among managers themselves. That is to say, they rarely adopted any substantial effort to counteract workers' non-cooperation on the shop floor. Such collective inaction from the management is partly due to the devious and elusive characteristic of this particular kind of resistance, which makes identifying concrete enemies and evidence hard. But more importantly, the issue is simply the reluctance of the management to take action. And such reluctance, I will argue below, stems from the strong sense of illegitimacy that is currently prevalent among the management in NS.

Among many other factors, such as the continuous losses of NS and the widening income gap between managers and workers, corruption is one of the most crucial factors that greatly delegitimize managers' position vis-à-vis workers. Corruption exists in NS not merely as rumors. Laowu, one retired senior manager, admitted to me that even though it is hard to estimate how extensive state asset losses due to corruption are, corruption among the highlevel managers, through channels of circulation, contract systems and most recently the restructuring process, are rampant. Numerous private factories were established in the suburb of NS, owned by the family members of these corrupt top-level managers. These people have 
become the 'rich abbots' in the 'poor temple' (穷庙富方丈). For the middle or lower-level managers, the most popular way to grasp money is to establish a nominal trading company 'under the table,' by retaining for his/her own company some contracts from the factory and using materials, equipment, and workers from NS. All these tricks are clearly recognized by workers, though perhaps not in exact detail, and the involved managers also know that workers know. Even though corruption has become such a 'popular' and even 'institutionalized' behavior in current Chinese society, it still brings about some uneasiness or qualms for managers, especially when they face workers. Occasionally, managers struggled hard to 'naturalize' their behaviors, as Amei, one lower-level manager, said to me:

'My colleagues are very nice. They all have their own ways to make money and nobody is jealous of you or blocks your way of making money. So, we have very good relationship with each other. A lot of my colleagues [all managers, author's note] have bought cars. I am thinking of buying a car too. (Pauses for a while) You know, we are all cutting the ground of state-owned enterprises. (Very uncomfortable) Last year NS lost another 400 millions. Nobody knows what will happen next, so I have to take advantage of the present to make more money, right?

\section{[Question: Don't you worry?]}

I don't think that much. No use. Anyway there are so many people in NS. (Pauses for a while) Sometimes I am worried. You know, what could I do if NS really goes bankruptcy? (Shaking his head) Well, forget it. You know, I am thinking of buying a bigger car for my family...'.

Amei's annual wage is around 30 thousand Yuan, but he told me that his actual income could reach more than 100 thousand Yuan per year, two thirds of which came from the socalled 'special ways'. He meant to boast to me, to convey that, even though he still stayed in NS, a bad place in other people's eyes, he was not a loser. Yet, during our conversation, he soon became unsettled about the topic, even though he chose to emphasize the 'normality' of such behaviors in the beginning by referring to his colleagues who were also making money in their own 'special' ways. 'Cutting the ground of state-owned enterprise' actually means stealing workers' labor. Realizing that brings so much uneasiness to these managers that they don't feel comfortable to confront workers when facing noncooperation and other silent resistances on the shop floor, unless their (the managers') interests are seriously damaged. Instead, most of the time, they adopt the strategy of avoidance and apathy, merely relying on the numerous rules and economic penalties for labor control. Many workers I interviewed believed that their managers (the sector chief and above) were distanced from them, didn't really care about the production, and only chased their own interests. Once, two workers, Dahua and Dali, described this kind of apathy for me vividly: 
'Dali: You can argue with them, but they just ignore you. It is different from before. Before, if you argued with them too impulsively, they would become angry and ask you to write a self-criticism. Now you can curse; they just pretend deaf.

Dahua: They know that our workers are resentful, so when you blow off your repressed emotion, they would just avoid you. They could bear these, since they don't have to work.

Dali: It doesn't relate to their interests. You can yell, cry, even bump your head against the wall---it doesn't matter to them.

Dahua: Ignore, just ignore.

Dali: There are two layers, separated from each other. Your business has nothing to do with theirs. You take your money, and they take their money.

Dahua: No matter how difficult the situation you are in, they will never help. They ignore you, since anyway your workers have to work to survive'.

Dahua is a female worker in her late 40s. She had been forcefully retired several years ago. Her younger brother, Dali, is a team leader, as well as an excellent electrician. Both of them were depressed and angry during the whole interview. Unlike during the Maoist era when managers were encouraged or forced to 'work side by side' with workers, now, they are superior 'bosses' separated from workers, both physically and emotionally.

Such reluctance and indifference is reflected among both managers and workers in the most popular expression, 'who cares'. Aqiu, the electrician, illustrated this indifference:

'From our analysis, these managers also don't really care. These equipments are not theirs. For our workers, it is the same. These equipments are not ours. It is not our factory, not mine, not yours. Sometimes we talk directly to the managers, "why did you manage that much? The factory is not mine, not yours, so how does it matter to you"? They know this. That's why they don't seriously discipline you; neither do they seriously make trouble to you'.

On the surface, such indifference seems to originate from the problem of ownership, as many neoliberal economists insist, and as Aqiu suggests here. But, in fact, this performance of indifference masks all kinds of anxieties and insecurities among both workers and managers in NS. Public ownership only becomes a problem when it ceases to grant dignity and security to people. With both workers' and managers' identification with the enterprise destroyed by neoliberal market reform, 'nobody cares'. Such double apathy, expressed by workers as one form of resistance, but also by managers as their response towards workers' resistance, has almost crippled the whole production process, doomed NS into its chronic 
losses, declared the complete failure of reform in NS, and finally, together with the failure of many other SOEs, made a mockery of the whole neoliberal SOE reforming agenda in China.

\section{WORKERS' HIDDEN COSTS IN THEIR EVERYDAY RESISTANCES}

If all these forms of everyday resistance are eating away at the regime in a persistent yet imperceptible way, what kind of consequences have they had for workers - the performers of this resistance? On the most obvious level, everyday forms of resistance have offered some safer outlets for workers to express their frustrations and grievances; to a certain extent, they have curtailed managers' controlling power in the shop floor; and presumably, they might even emit some subdued but desperate signals that have been sensed by the government, and hence contributed to measures that have helped to delay their final unemployment. Yet beyond all these, my ethnographic research has revealed another more hidden effect these particular forms of resistance have imposed on workers, that is, the psychologically detrimental effect on them. I argue that workers' everyday resistance, expressed as it is through quite passive and negative ways, actually goes against the moralities generally held by most NS workers, distances them from their work, shatters their sense of honor and pride, and strengthens their feeling of inadequacy and powerlessness.

Even though they are exposed to the emerging money worship and utilitarianism that has been wholeheartedly embraced by the middle and upper class in current Chinese capitalist society, many workers I know in NS still hold fast to some basic moral principles that they inherited from the older working-class generations, learnt from their school education, and possess as part of human nature. Honesty, righteousness, and industriousness still constitute the ethical framework through which workers can claim their dignity and pride. However, all the spontaneous forms of everyday resistance adopted by currentlyemployed workers - foot-dragging, apathy, pilferage - actually run counter to these virtues.

To illustrate this argument, consider again the description given earlier by Abin of workers apathetically watching both machines and managers falling into disorder and doing nothing. Although such inaction serves as a form of revenge against managers, there is also a paradox hidden in this strategy: in order to resist against the management, workers have to be antagonistic against their own jobs. That means, they have to restrain themselves from the fulfillment and pride they could have felt by their labor, for example, through successfully solving problems in this case, instead standing aloof and hostile, not only from their managers, but also from their own labor. A similar process of self-estrangement and antagonism can also be found in foot-dragging. It actually forces workers to doubt further the meaning of their work and sometimes, their own right to continued employment; as many workers said half-joking to me, 'We really should be laid off. When I asked Abin if he felt satisfied acting in such ways, he shook his head bitterly and said, 'No, I feel sad. It is just ridiculous'. Abin entered NS in the early 1980s. He had been renowned for his exquisite skill factory-wide and hence awarded many times as a model worker in the 1980s and early 1990s. Now, almost in his 50s, he asked me if there is any opportunity for him to migrate to the U.S. as a coolie. 
A more acute paradox for workers comes from the pilferage that goes beyond selfestrangement and actually challenges many workers' moral baseline. Even though many of the workers I interviewed always defended other workers' pilferage strongly and eagerly, almost everyone would add, 'But I will not do those kind of thing'. It was always other people, not they who stole. Such efforts to distance themselves from such behavior might not necessarily come from their distrust toward me for fear of being reported since a strong sense of trust has already been established between us while I was in the field, but more likely from their deep shame toward it. It brings humiliation and disgrace to them. Even though they, themselves, might not be involved, as they claimed to me, they must know by instinct how easily and conveniently the image of the whole working class, like any subordinate social groups, could be stereotyped and stained by such deeds, even if performed only by some. In other words, these strategies of resistance have, in some ways, deprived workers of the pride and even legitimacy that could derive from clearly claiming their rights and proudly confronting the management.

Such everyday strategies have also, combined with other dilemmas, brought pain - a feeling that does not just originate from poverty or deteriorating social status, but also from a sense of powerlessness and of having 'no way out.' As described by Richard Sennett and Jonathan Cobb (1972: 58), it is 'the feeling of not getting anywhere despite ones' efforts, the feeling of vulnerability in contrasting oneself to others at a higher social level, the buried sense of inadequacy that one resents oneself for feeling'. Often, when the pain became unbearable, workers choose to numb themselves in different ways. For example, gambling/playing Majiang have become the most popular entertainment among NS workers and managers, everywhere from teahouses, Majiang houses, parks, people's homes, to the night-duty rooms of the workshop. Job insecurity, the depressing future of the factory, the anxieties of survival or making money, strong feelings of humiliation or illegitimacy, all of these have brought people to the gambling table. At least by cheering or contesting every small gain or loss, they can escape from their unhappy reality, even if only briefly. When I asked Xiaoxia, a steelworker in his early 30s, why he spent so much time on the Majiang table, he smiled shyly, 'you have nothing to do here. Playing Majiang makes me happy; otherwise, I might go crazy'. Pausing for a while, he added uneasily, 'I am hopeless'. Dali, the worker in his late 40s sharply pointed out, 'Gambling is one way to numb us. Everybody plays Majiang because we don't have any inner resources to support ourselves'.

What we can see from the descriptions above is that all these forms of resistance enacted by currently employed workers in NS - curses, apathy, foot dragging, irresponsibility, pilferage, gambling, and so on - have not empowered them. Instead, they constantly contradict with and challenge the moral values they held strongly before, and hence further strengthen their sense of inadequacy. When I asked the workers I interviewed whether they would rebel if NS went into bankruptcy, almost all of them replied in a very similar way: 'No, I think I will just leave to find another job somewhere'. 


\section{Conclusion}

The claim of 'where capital goes, conflict follows' (Silver and Zhang 2009) is certainly apt in highlighting the agency of subordinate groups - their willingness and capability to fight against the oppressive regime and try to control, at least partly, their own fate. But we have to be careful not to push this claim further to assume that the working class, by organizing unions, developing modes of collective representations and collective bargaining, and initiating demonstrations, strikes, or any other forms of collective resistances, will eventually develop an equally counter-balanced power against capital (private or state). This assumption, which is widely accepted by many labor study scholars from the branch of so-called 'comparative studies of advanced capitalism', follows the idea of labor as a 'social partner' within a triadic power relation, one which negotiates and bargains equally and constantly with the other two social partners: capitalists and the state (Eberwein, Tholen and Schuster 2002; Streeck 1984, 1989; Tilly and Tilly 1998). Such argument hence blurs the systematic and structurally unequal power relations between different social actors, while assuming the existence of a counterbalanced and hence democratic labor bargaining mechanism in advanced capitalist countries. However, such illusion has already been smashed by the coming of global capitalism, whereby unions and collective bargains suddenly became emaciated and common workers quickly lost what fragile fruit they had arduously achieved through hundreds of years of struggle and sacrifice. These harsh realities only throw into sharp relief the oppressive system itself and the vulnerability and limitations of the subordinated groups' struggle.

This article has provided another quite paradoxical and dismayed image of workers' resistance in one state-owned enterprise in China, another crucial player in the current game of global capitalism. It has revealed how workers there have responded to the sweeping neoliberal reforming agenda and the emerging capitalist labor relationship. It then serves as a complementary work to the current Chinese labor movement studies that mainly focus on workers' collective and militant resistance. Workers in China do resist. But as I have illustrated, to a large extent, they are able to do so only within a highly pressurized and constrained space. Unlike leftist, middle-class intellectuals, many of whom possess the privilege of contemplating the bigger world, choosing their political positions, and even putting their political proposals into meaningful actions, common workers, like many other subordinate classes, have to face a much rougher reality: they have to manage to survive and feed their family first, the right of which might be constantly threatened by the regime. In that sense, as revealed in this study, the forms of resistance taken by workers have to be circumvented, veiled, distorted, and sometimes even against their morality and nature. While these everyday resistances have certainly damaged the regime, they have also alienated, disempowered, and subordinated workers themselves.

Once in the field, when I was talking with several workers in their work cell, one worker leaned over to me and asked, 'you come from the United States, so can you tell me, are the workers there happier than us?' All the other workers looked at me and waited for the answer eagerly. I hesitated for a while, and then said, 'I cannot tell on their behalf. But I guess maybe not'. All of them laughed and then the worker continued, 'So can they afford 
houses? Dare they go to the hospital when they are sick? Do they worry about the tuition fee for their kids'? When I told them that the working class in the United States has to face their own problems, they laughed bitterly again, yet sounded half-relieved, and one said, 'so, workers everywhere are the same, small'.

The only thing left uncertain is just how these 'small' resistance taken by these 'small workers', together with other more militant and collective ones, will eventually shape the

world as it continues to change, rapidly, violently, and with such widening inequality and unpredictability.

\section{ACKNOWLEDGEMENT}

My biggest debt in writing this paper goes to the workers I interviewed for generously sharing their experiences with me. I thank them especially for their trust. I am grateful to Professor Mahua Sarkar, Professor Frederic Deyo, Professor Leslie Gates, and Kim Greenwell for reading and commenting on this paper. I would also like to thank the anonymous reviewers for GLJ for their useful comments and the manager editor, Kara Vincent, for making this publication possible.

\section{NOTES}

1. The detailed illustration of the despotic factory regime in NS can be found in Li's work (2012).

2. The detailed illustration of the disintegration and the segregation of the working class community can be found in Li's work (2012).

3. The pensioners in Nangfang Steel did organize effective and militant collective resistance since the 1980s. See Li's work (2012).

4. Once, Dayong, a steelworker in his early 30 s, elaborated to me the changing images printed on the bills to illustrate how the state is abandoning workers: the images of steel workers and lathe workers previously printed on the Five-Yuan and Two-Yuan bills have disappeared from the newest version of bills. 


\section{REFERENCES}

Bartha, E. (2005) 'Workers after the Workers' State: Ethnography of Change in an ExSocialist Model Factory', in T. Krausz and P. Szigeti (eds), ESZMELET CONSCIOUSNESS (pp. 64-93). Budapest: Periodical Eszmelet.

Blecher, M.J. (2002) 'Hegemony and Workers' Politics in China', The China Quarterly 2002(170): 283-303.

Bloch, M. (1970) French Rural History. Trans. Janet Sondheimer, Berkeley: University of California Press.

Cai, Y. (2002) 'The Resistance of Chinese Laid-Off Workers in the Reform Period', The China Quarterly 2002(170): 327-344.

Cai, Y. (2006) State and Laid-Off Workers in Reform China: The Silence and Collective Action of the Retrenched. London: Routledge.

Chan, A. and Unger, J. (2009) 'A Chinese State Enterprise under the Reforms: What Model of Capitalism?', The China Journal 2009(62): 1-26.

Chen, D. (1997) 'From "The Plan of Food, Clothing and Daily Necessities" to "Preparing the War" - The Changing Process of the Third-fifth Thoughts' [in Chinese], Contemporary Chinese History Research 1997(2): 65-75.

Chen, F. (2006) 'Privatization and Its Discontents in Chinese Factories', The China Quarterly 2006(185): 42-60.

China News (2010) ‘317,000 Labor Dispute Cases' [in Chinese], 11 March 2010. Available at: http://www.chinanews.com/gn/news/2010/03-11/2164257.shtml. [Accessed 12 December 2010].

China Statistic Yearbook 2009 (2009) National Bureau of Statistics of China, Beijing. Available at: http://www.stats.gov.cn/tjsj/ndsj/2009/indexeh.htm. [Accessed 26 January 2011].

Dyer, G. and McGregor, R. (2008) 'China’s Champions', Financial Times, 16 March 2008.

Eberwein, W., Tholen, J. and Schuster, J. (2002) The Europeanisation of Industrial Relations: National and European Processes in Germany. Aldershot, UK: Ashgate. 
Ferguson, J. (1999) Expectations of Modernity: Myths and Meanings of Urban Life on the Zambian Copperbelt. University of California Press.

Friedman, E., Pickowicz, P.G., Selden, M. and Johnson K.A. (1991) Chinese Village, Socialist State. New Haven/London: Yale University Press.

Gallagher, M.E. (2005) Contagious Capitalism: Globalization and the Politics of Labor in China. New Jersey: Princeton University Press.

Gaventa, J. (1980) Power and Powerlessness: Quiescence and Rebellion in an Appalachian Valley. Urbana: University of Illinois Press.

Guo, Y. and Hu, A. (2003) 'The Administration Monopoly, Rent-seeking and Corruption An Analysis of Corruption During the Transitional Economy' [in Chinese], Comparative Economic \& Social Systems 2003(2): 61-69.

Hobsbawm, E.J. (1965) Primitive Rebels: Studies in Archaic Forms of Social Movement in the $19^{\text {th }}$ and $20^{\text {th }}$ Centuries. New York: Norton.

Huang, Q. (2006) 'The New Characteristics of Management Corruption and the New Stage of SOE Reform' (in Chinese), Industrial Economy in China 2006(11): 52-59.

Lee, C.K. (1998) 'The Labor Politics of Market Socialism: Collective Inaction and Class Experiences Among State Workers in Guangzhou', Modern China 24(1): 3-33.

Lee, C.K. (2000) 'Pathways of Labor Insurgency', in E.J. Perry and M. Selden (eds.), Chinese Society: Change, Conflict and Resistance (pp. 41-46). London: Routledge.

Lee, C.K. (2002) 'From the Specter of Mao to the Spirit of the Law: Labor Insurgency in China', Theory and Society 31(2): 189-228.

Lee, C.K. (2007) Against the Law: Labor Protests in China's Rustbelt and Sunbelt. Berkeley: University of California Press.

Li, J. (2012) All That is Solid Melts Into Air: an Exploration of the Transformation Process of a Third-front Enterprise in China. Binghamton University: Doctoral Dissertation.

Liu, A. (2005) Choices: State-owned Enterprises Reform and the Workers' Subsistence Action [in Chinese]. Beijing: Social Sciences Academic Press.

Ma, Q. (1998) The Industrial History of New China [in Chinese]. Beijing: Jinji Guanli Publisher. 
NS Annual Report (2008) NS Company Documents.

Ngai, P., King, C. Chan, C. and Chan, J. (2009) 'The Role of the State, Labour Policy and Migrant Workers' Struggles in Globalized China', Global Labour Journal 1(1): 132151.

Oi, J.C. (1991) State and Peasant in Contemporary China: the Political Economy of Village Government. Berkeley: University of California Press.

Pei, M. (2003) 'Rights and Resistance: The Changing Contexts of the Dissident Movement', in E. Perry and M. Selden (eds), Chinese Society: Change, Conflict, and Resistance (pp. 23-46). London: Routledge Curzon.

People's Daily: Sichuan (2010) 'The Average Wage in Sichuan decreased in 2009' [in Chinese], 15 May, $2010 . \quad$ Available at: http://sc.people.com.cn/news/HTML/2010/5/15/20100515092004.htm. [Accessed 24 April 2012].

Fox Piven, F. and Cloward, R.A. (1977) Poor People's Movements: Why They Succeed, How They Fail. New York: Vintage.

Scott, J. (1987) Weapons of the Weak: Everyday Forms of Peasant Resistance. Yale University Press.

Sennett, Richard and Cobb, Jonathan (1972) The Hidden Injuries of Class. New York: W.W. Norton \& Company.

Silver Beverly (2003) Forces of Labor: Workers' Movements and Globalization since 1870. Cambridge: Cambridge University Press.

Silver, B.J. and Zhang, L. (2009) 'China as an Emerging Epicenter of World labor Unrest', in Hung, H-F. (eds) China and the Transformation of Global Capitalism. Baltimore: The Johns Hopkins University Press.

Streeck, W. (1984) Industrial Relations in West Germany: A Case Study of the Car Industry. Portsmouth: Heinemann Educational Books Ltd.

Streeck, W. (1989) 'Skills and the Limits of Neo-Liberalism: The Enterprise of the Future as a Place of Learning', Work, Employment, and Society 1(3): 281- 308.

Tilly, C and Tilly, C. (1998) Work under Capitalism. Westview Press. 
Yu, J. (2010) 'Conflicts Between Officials and Citizens are the Key to Mass Incidents' [in Chinese], China Report 2010(1): 50-51.

\section{BIOGRAPHICAL NOTE}

JU LI is a doctoral candidate at Sociology Department Binghamton University, New Jersey, USA. [e-mail: lijuliju@yahoo.com] 